\title{
Does Size Moderate Sustainability Practices and Performance of Construction Companies in
} Malaysia?

\author{
Muhammad Izhuan Abdul Manaff ${ }^{1}$ \\ Norziana Lokman ${ }^{2 *}$
}

Nor Suziwana Tahir

\author{
${ }^{1,5}$ Faculty of Administrative Science and \\ Policy Studies, Universiti Teknologi \\ MARA, Shah Alam, Malaysia. \\ ${ }^{2}$ Email: izhuanmanaff@uitm.edu.my \\ ${ }^{s}$ Email: suziwana@uitm.edu.my \\ -Accounting Research Institute, \\ Universiti Teknologi MARA, Shah \\ Alam, Malaysia. \\ Email:norzi716@uitm.edu.my \\ Licensed: \\ This work is licensed under a Creative \\ Commons Attribution 4.o License. \\ Keywords: \\ Sustainability \\ Construction industry \\ Balanced scorecard \\ Company performance.
}

Accepted: 16 September 2019

Published: 25 September 2019

\begin{abstract}
This paper examined the moderating role of company size on the relationship between sustainability practices (social, environmental and economic) and performance of companies in the construction industry in Malaysia. A total of 247 out of 389 construction companies located in Kuala Lumpur and Selangor, Malaysia responded to the questionnaires. The study found that economic and environmental practices of sustainability were positively and significantly related to company performance. However, a social practice of sustainability has no relationship with company performance. Finally, the company size was found to have no moderating effect on the relationship between all sustainability practices (social, environmental and economic) and company performance. The unexpected results of the company size may be due to the lack of understanding and unwillingness of companies in the construction industry to change and adopt sustainability practices. In addition, inadequate enforcement in respect of laws and regulations may have contributed to the lack of sustainability practices implemented in construction industry.
\end{abstract}

Funding: This study received no specific financial support.

Competing Interests: The authors declare that they have no competing interests.

\section{Introduction}

The concept of sustainable development has been defined by the United Nations' World Commission on Environment and Development (WCED) as development that meets the needs of the current generation without compromising the ability of future generations to meet their needs (United Nations General Assembly, 1987). The definition provided by the WCED is helpful but lacks clarity (Chang et al., 2017). The sustainability concept aims to guarantee economic prosperity, good quality of life for humans and non-human while protecting the environment. The Triple Bottom Line theory identifies the three main elements of sustainability which should be the focused of companies, namely social, environmental and economic (Stenzel, 2010). For the company to be sustainable the company should be able to balance all these three elements. According to Chang et al. (2017) at the early stage sustainability theories are concerned about what sustainability means and what practices are considered sustainable. Now the shift is focused on how to promote sustainability in companies. Thus, the sustainability theories have changed from "what" to "how" companies should incorporate sustainability practices in their daily operations.

The majority of companies in building construction in the world believe in the concept of sustainability and understand that attention must be given if they wish to survive and strive for a long period. Members of the public also believe that sustainability is an important issue and today people have much more knowledge and understanding of the preservation of the environment. This has led to further demand for the construction industry to take more effort into sustainability practices especially in maintaining environmental health. The public demand is that in course of construction development, the element of sustainability must be taken into consideration not just for the sake of regulations, but also as industrial responsibility.

The construction industry in Malaysia experienced a steady contribution to growth domestic product (GDP) for the past five years (2012-2016). It contributes on average about $9.4 \%$ to the income component of 
Malaysia (Department of Statistics Malaysia, 2018). Based on the survey done by Zainul (2009) it is reported that Malaysian companies are aware of sustainable concepts however they are lacking in terms of implementation. This means that they are not willing to change the way they do business. The reason is that most of them viewed sustainability practices would only increase cost rather than helping the company to maintain and increase profits. Besides, they have a misconception that sustainability is only about protecting the environment without realizing that sustainability is also about harmonizing the other two elements which are social and economic (Zainul, 2010).

The construction industry is important in terms of contribution to Gross Domestic Product (GDP) and at the same time, it is also one of the major contributors to pollution in the world environment. The construction, maintenance and use of buildings have a crucial impact on environmental, social and economic changes. According to Roodman and Lenssen (1995) construction activities across the world have consumed 40 percent of all raw materials available and useable. Due to this condition, the use of sustainable building materials and the implementation of sustainable construction activities can help improve the global environment significantly (Roodman \& Lenssen, 1995). Currently, there is an urgent need for solutions and methods that can save the environment and simultaneously provide better and eco-friendly living or working space that will improve the health and livelihood of humans (D'amato, Henderson, \& Florence, 2009). Also, issues on sustainability of companies has become a focal point among researcher because companies are the valuable source of the economy and play an important role in helping the world to achieve sustainable agenda (Chang et al., 2017).

For the construction industry, social sustainability requires integrating processes to improve safety, health, and well-being over the project life cycle (Valdes-Vasquez \& Klotz, 2012). Therefore, the social practice of sustainability is a crucial aspect that needs to be paid more attention because it directly influences the people or the communities' well-being. Companies are demanded by the public to change their ways of conducting their activities that have affected the societies and the natural environment whether directly or indirectly. Companies are also required to embrace sustainability practices into their daily operations in which they performed their businesses and activities. D'amato et al. (2009) stated that it is no longer acceptable for corporations to only focus on economic prosperity. Meanwhile, the people or society that directly or indirectly involved are affected negatively. Thus, companies must realign their strategic plan by focusing their attention on maximizing benefit, minimizing harm and be responsive to various stakeholders' expectations to survive.

Companies have to keep updating their sustainability practices in line with the sustainability of global trends and have the financial obligations to sustain and maintain for both private and public benefits. For these reasons, companies are forced to reform their frameworks, regulations, and business models to understand and enhance current efforts in implementing sustainability practices. Thus based on the above discussion, this study aims to investigate the influence of sustainability practices (social, environmental and economic) on the performance of the companies in the building construction industry in Malaysia. The paper is organized as follows: the next section presents the hypothesis development of the study and then followed by the methodology section, the next finding, and the discussion section, and lastly, the conclusion and future recommendation section of the study is presented.

\section{Hypotheses Development}

2.1. Social Sustainability Practice

Zairi and Peters (2002) has identified the key critical success factors that can improve company performance. They found that social activities such as community focus, stances on safety and the environment and external activities using best practice examples make social activity counts. A study by Saeidi, Sofian, Saeidi, Saeidi, and Saaeidi (2014) found that the social practice of sustainability has a positive relationship with the company performance. According to Wang (2014) sustainability practices help build a positive reputation for the company and attract customers to use its services again. This leads to an increase in company performance due to more customers requiring their products or services. A study by Marshall and McCarthy (2013) found that the social practice of sustainability has a positive influence on operational and financial performances. In addition, Weber and Remer (2011) also found that there is a positive relationship between sustainability practices and company performance. Thus, based on the results of prior studies on the relationship between social practices and company performance, this study proposes the following hypothesis:

\section{$H^{I}$ : There is a positive relationship between social practices of sustainability and company performance.}

\subsection{Environment Sustainability Practice}

Environmental issues statement and green project were rank as the first criteria that present the sustainability practice for property companies in Malaysia which were reported in annual reports and websites (Newell \& Manaf, 2008). Companies that actively involved in environmental practice can influence the employee perceptions towards the companies and their behavior will change to be more efficient and more dedicated to their jobs. The environmental elements need to be taken care of for the company's reputation to grow and with it the company's performance. A study by Haddach, Ammari, and Laglaoui (2016) showed that the environmental practice of sustainability is likely to improve the overall performance of the company. 
Another study by Orlitzky, Schmidt, and Rynes (2003) also found that there is a moderate correlation between environmental practice and company performance. Accordingly, this study argues that environmental practices influence company performance and proposes the following hypothesis:

$H^{2}$ : There is a positive relationship between environmental practices of sustainability and company performance.

\subsection{Economic Sustainability Practice}

Becker and Gerhart (1996) stated that human resources, both as labor and as a business function, has traditionally been viewed as a cost to be minimized to achieve optimal performance. In economic sustainability, the management of company human resources or cost can influence the company business and ultimately their performance. Research by Balabanis, Phillips, and Lyall (1998) showed that some elements in sustainability economic practice can influence the company performance. Also, Choi and Yu (2014) found that sustainability practice influenced company performance by preserving stakeholder relations. A prior study by Saeidi et al. (2014) also found that the economic practice of sustainability practices has a positive relationship with company performance. Furthermore, Maletic, Maletic, Dahlgaard, Dahlgaard-Park, and Gomiscek (2015) found that by practicing sustainability the companies can efficiently increase their performance and innovation process. Based on the above discussion, we hypothesize that:

\section{$H^{3}$ : There is a positive relationship between economic practices of sustainability and company performance.}

\subsection{Moderating Role of Company Size}

A previous study by Haddach et al. (2016) found that there is a positive moderating effect between company size and company performance. The study conducted by Pervan and Višić (2012) showed that company size has a weak positive influence on the company's performance. They believe that this is because of the effect of market power that the company is currently involved in. Pervan and Višić (2012) found that a larger company can charge higher prices for their products and claim profits and increase performance at the end. Additionally, higher performance could also be a result of economies of scale and stronger negotiating power possessed by the company resulting in more favorable financing conditions.

Real, Roldán, and Leal (2014) showed that with company size as a moderating variable, business management appears to have a greater improvement. The size of the company allows them to learn with more flexibility and adaptability in a shorter time and take advantage of new opportunities appearing in the industry. Another study by Abbasi and Malik (2015) showed that the size of the company influenced the company performance. The research also showed that the bigger the company size is the more the company can performed. Doğan (2013) research also found that there is a positive relationship between the size of the company and the company performance. Doğan (2013) research results showed that company performance increased as the company size expands.

An empirical study by Amah, Daminabo-Weje, and Dosunmu (2013) showed that the size of the company can affect its performance. The company needs to be on the right size so it cannot be overemphasized. Company performance increases with an increase in responsiveness and flexibility that usually present in small sizes. Meanwhile, a large company can achieve this feat by the creation of several branches and the decentralization of its business activities. All this can lead the company to be more responsive to its customers.

A previous study by Surajit and Saxena (2009) showed that company size as a main factor of company financing structure which comprised of the company production and turnover capacities. Others also suggested that the company size is the main element that forms the scale and scope of the company's financial structure and a critical requirement for the company to keep surviving in the industry. Other critical variables such as the company's strategic style, company performance, and manager service risks were dwarfed by the influence of company size (Veliyath, Ferris, \& Ramaswamy, 1994).

However, the study conducted by Cody, Hegeman, and Shanks (1987) stated that not all of the elements in the company size can influence performance. Some of the traditional elements such as multiple levels of supervision and the number of employees are not significant in achieving optimum performance. Consistent with the prior study, Niresh and Thirunavukkarasu (2014) also found that there is no suggestive influence between the size of the company and company profit in manufacturing company in Sri Lanka. They suggested that no relationship is due to inefficiency in the management process in utilizing its assets and this leads to excess production and poor inventory management. Thus, the size of the company does not represent how much of the potential performance can be achieved by the organization.

In this study, we proposed that a bigger company would have better capacity and resources to implement social practice such as sponsorship, donation, charity, and community work. These would later be translated into a better reputation of the company that results in higher profits. In term of environmental practices, size of company do matters because society does expect that bigger company to be more ethical in doing their business and are willing to protect the environment to save their good image especially went they have plants in other parts of the world. International people would be monitoring the bigger company behavior more compared to the small company. In addition, a bigger company would gain more benefits because they can 
monopolies the economies of scale which lower the company costs and improve profits thus able to survive and sustain better than a small company. Therefore the study hypothesized the following:

$H^{4 a}$ : The size of the company moderates the relationship between social practices of sustainability and the performance of the company.

$H^{4 b}$ : The size of the company moderates the relationship between environmental practices of sustainability and the performance of the company.

$H^{4 c}$ : The size of company moderates the relationship between economy practices of sustainability and the performance of the company.

\subsection{Company Performance}

The dependent variable of this study is the company performance. All process of measuring performance requires a certain statistical model or formula to determine company performance. A complete measurement that covers all aspects of the performance of a company can never be obtained because some of the criteria cannot be measured directly, for example, non-financial items such as corporate image and goodwill that can only be measured through observation. Prior studies have used various methods of performance measurements: Economic Profit or Economic Value Added (Friedl \& Deuschinger, 2008) accounting profits (Ryan, 2011) and financial ratios (Otley, 2003). However, using these financial measures for company performance will not able to predict a company's future performance as the data used are historical data (Chan, 2009).

In this study, a balanced scorecard (BSC) is used to measure company performance. Kaplan and Norton first introduced the BSC in 1992 as a proxy to measure company performance. The BSC performance measurement consists of four perspectives, namely, financial, internal business process, learning \& growth and customer (Chan, 2009; Kaplan \& Norton, 1992; Kaplan, Norton, \& Rugelsjoen, 2010). In this study, the BSC is used to measure company performance for four main reasons. First, BSC is a more comprehensive tool that covers all aspects of the business and assists improvements of the environment, social and financial business goals management, thus fulfilling the requirements of the sustainability concept. Second, the BSC provides a fast but comprehensive view of the company's performance and includes both process and results measures. Third, the BSC also includes non- financial aspect that can be a factor to decrease or increase in company performance such as the customer perspective. Fourth, the BSC has been widely adopted and is the most popular performance management framework (Rigby \& Bilodeau, 2014) used by many researchers.

\subsection{Conceptual Framework}

Based on the objective of this study that is to investigate the influence of sustainability practices (which consist of social, environmental and economic) and company performance. The independent variables identified were based on the Triple Bottom Line theory introduced by Elkington (1997) and the instrument used for company performance was adapted from Kaplan et al. (2010) and Kaplan and Norton (1996) and other related studies (Rigby \& Bilodeau, 2014). The conceptual framework of the study is presented in Figure 1.

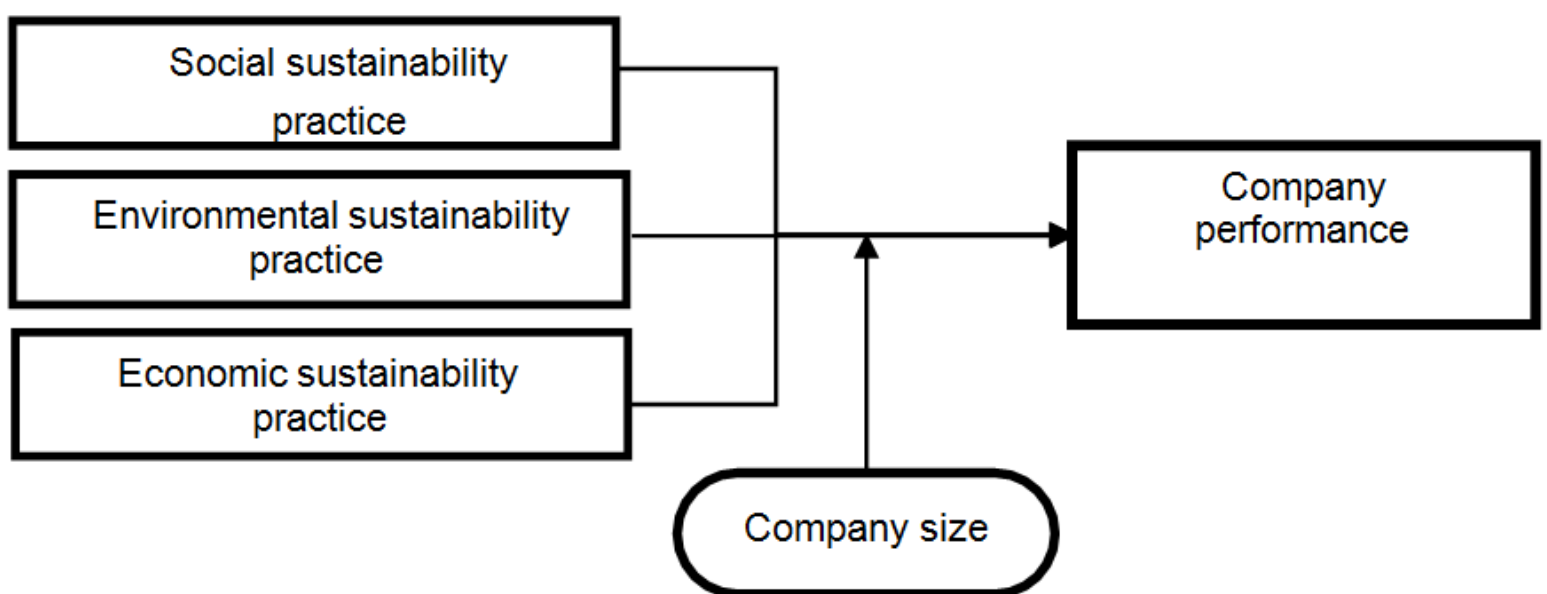

Figure-1. Conceptual model of sustainability practices, company size and company performance. Source: Research on framework and literature review.

\section{Methodology \\ 3.1. Sample and Data Collection Method}

The construction industry covers the aspects of the planning, design, conservation, demolition and repairing various types of buildings and all types of mechanical and civil engineering works either as general or specialist contractors (Ofori, 1990). As such a person or company that provides consultancy services on 
design and planning of building and works does not fall under the construction industry and is excluded from this study.

The list of construction companies is obtained from the Real Estate and Housing Developers' Association Malaysia (REDHA). This study focuses on the construction companies located at Selangor and Kuala Lumpur. As at 31 December 2016 there were 389 construction companies operated in Selangor and Kuala Lumpur. Selangor and Kuala Lumpur are chosen because a bigger number of construction sites and housing developers are concentrated in the area. Since the sample size is small, the researcher decided to include all 389 companies for the study. Thus, no sampling technique is used for this study. This technique is known as the population survey or census method.

Data for the study were collected through a structured administered questionnaire. The questionnaires were distributed between February 2015 and September 2015. A total of 389 respondents were approached and 247 (63\%) questionnaire were returned for analysis. The data collected were analyzed quantitatively. Descriptive analysis was used to describe the basic profile of the companies involved in the study. Process analysis was run to test the moderating effect of company size and the correlation and regression analysis were used to test the relationship between social, environmental and economic sustainability practices and company performance.

\subsection{Instrumentation}

The questionnaire comprised of eight sections: Section A (Demographic profile of the respondents); Section B (Assessing the respondents' experiences and feedbacks concerning the social sustainability practice of their company using '5-point Likert' scale); Section C (Assessing the respondents' experiences and feedbacks concerning the economic sustainability practice of their company using ' 5 -point Likert' scale. Section D (Assessing the respondents' experiences and feedbacks concerning the environmental sustainability practice of their company using ' 5 -point Likert' scale. Section E to H contained 40 items that assess the company performance.

The items in the questionnaire for section B, C and D were developed based on John Elkington's triple bottom line elements of sustainability namely, social, environmental and economic (Elkingtone, 1998). Meanwhile, items to measure company performance in section $\mathrm{E}$ to $\mathrm{H}$ is based from the four key perspectives of balanced scorecard (BSC) developed by Kaplans (2010); Kaplan and Norton (1992) and Chan (2009). The four key perspectives of BSC namely, financial, internal business process, learning and growth, and customer. The following Table 1 presents the measurement instruments of the variables used in the study. Please refer to Appendix A for the full set of the questionnaire.

\begin{tabular}{|c|c|c|c|}
\hline Variables & $\begin{array}{l}\text { Number of } \\
\text { items }\end{array}$ & Source of scale & Type of scale \\
\hline Company performance & 40 & $\begin{array}{l}\text { Kaplan and Norton (1992); } \\
\text { Kaplans (2010); } \\
\text { Chan (2009) } \\
\end{array}$ & 5- points Likert scale \\
\hline $\begin{array}{l}\text { Social sustainability practices } \\
\text { Environment sustainability } \\
\text { practices } \\
\text { Economy sustainability practices }\end{array}$ & $\begin{array}{l}10 \\
10 \\
10\end{array}$ & Elkington (1997) & 5- points Likert scale \\
\hline Company size & 1 & $\begin{array}{c}\text { Beaver, Griffin, and } \\
\text { Landsman (1985); Shehata } \\
\text { (1991) }\end{array}$ & $\begin{array}{c}\text { Revenue or total } \\
\text { sales }\end{array}$ \\
\hline
\end{tabular}

Source: From the researcher literature review.

\section{FINDING \& DISCUSSION}

\subsection{Reliability Analysis}

Based on the results given in Table 2, it shows that the Cronbach's alpha value for all variables in the study ranges from 0.827 to 0.955 , which are all above 0.6 and thus acceptable (Hair, Babin, \& Black, 1995). The results of the reliability test indicated that the questions used in the questionnaires had a high level of internal consistency. 
Table-2. Pilot study reliability test.

\begin{tabular}{l|c|c}
\hline Variables & Cronbach's alpha & Number of items \\
\hline Independent variables: Social practice & \\
economic practice environmental & 0.955 & 10 \\
practice & 0.827 & 10 \\
& 0.901 & 10 \\
\hline Dependent variable: Company & 0.912 & 40 \\
performance & & \\
\hline Source: Research's analysis. & & \\
\end{tabular}

\subsection{Descriptive Statistics}

The findings showed the distribution of the company was higher for private companies with a total of 121 or 49 percent companies. On the other hand, there were 45 or 18 percent public companies out of the total 247 companies. The remaining 81 companies or 32 percent are subsidiaries companies. The location of the companies showed that the majority of the companies (55\%) are located in Selangor while the rest (45\%) are located in Kuala Lumpur. For years of establishment, the results showed that 33.6 percent of the companies have been in the industry for six to 20 years. This indicated that most of the companies in Selangor and Kuala Lumpur are well established and have an adequate amount of experience in the construction industry. In terms of size of the companies, the finding showed that most of them were small in size with a range of annual sales turnover of less than RM5.0 million (74\%) and the remaining (26\%) is categorized as large company with annual sales turnover above RM5.0 million.

\subsection{Process Analysis}

The study proposed that size of company moderate the relationship between social, environmental and economic sustainability practices, and company performance. The process test is a method of testing the significance of a moderating effect. In this study, the process test is run on the sustainability practices which are the social, economic and environmental and the company performance.

Table-3. Process test: Moderating effect of company size.

\begin{tabular}{c|c|c|c|c}
\hline \multicolumn{5}{c}{ Process } \\
\hline & $\mathbf{t}$ & $\mathbf{p}$ & LLCI & ULCI \\
\hline Social xDv performance & -0.8584 & 0.3915 & -0.1157 & 0.0454 \\
\hline Environment xDv performance & -0.7085 & 0.4793 & -0.0785 & 0.0370 \\
\hline Economical xDv performance & -1.4904 & 0.1374 & -0.1391 & 0.0193 \\
\hline
\end{tabular}

Source: Research's analysis.

The results in Table 3 showed that there is no interaction between the social, environmental and economic of sustainability practices with the dependent variable which is the company's performance. The pvalue of social practice is 0.3915 . For environment practice, the $p$-value is 0.4793 and economic practice the $p$ value is 0.1374 . The fact that the observed p-value exceeds 0.001 indicates that there is no interaction between the independent variable and the dependent. It can be concluded that there is no moderating effect of the company size on the relationship between all sustainability practices (social, environmental and economic) and the performance of companies. Thus company size is not included when correlation and regression analysis is conducted.

\subsection{Correlation Analysis}

Table 4 presented the result of the correlation analysis. The result shows that there was a significant positive correlation between the social practice of sustainability and the company's performance $(r=0.246, p$ $=<0.001)$. Next, the environment practice of sustainability has a positive and significant correlation with company performance $(\mathrm{r}=0.519, \mathrm{p}=<0.001)$. Finally, the economic practice of sustainability also has a significant positive correlation with company performance $(r=0.409, \mathrm{p}=<0.001)$. Overall, these correlation results provide initial support for the majority of the hypotheses in the study.

\begin{tabular}{c|c|c|c}
\hline \multicolumn{5}{c}{ Table-4. Correlation analysis. } & \\
\hline Variable & $\mathbf{1}$ & & \\
\hline Company performance & & 1 & \\
\hline Social & $.246^{* *}$ & $.234^{* *}$ & $.424^{* *}$ \\
\hline Environment & $.519^{* *}$ & $.266^{* *}$ & $.409^{* *}$ \\
\hline Economic & \multicolumn{2}{c}{. }
\end{tabular}




\subsection{Regression Analysis}

Regression analysis was carried out to determine which sustainability practice has a higher impact on company performance. From the results in Table 5, it is shown that the sustainability practices namely environment, social and economic practices explains about $32.1 \%$ of the variance of the company performance $(\mathrm{R} 2=.321)$. The $\mathrm{F}$ value is 38.34 and the p-value is significant at 0.001 . This indicated that the regression model statistically and significantly predicts the company performance. The Durbin-Watson value is 1.671 , which is between the two critical values of 1.5 and $2.5(1.5<\mathrm{d}<2.5)$, which indicate that there is no linear or serial correlation in multiple regression data. Based on the result, the assumptions are there is no linear or serial correlation in multiple regression data.

\begin{tabular}{|c|c|c|c|}
\hline & Predicted sign & Standardized coefficients & $\mathbf{t}$ \\
\hline & & $(\beta)$ & \\
\hline (Constant) & & $1.389^{* * *}$ & 7.931 \\
\hline Social & + & .094 & 1.693 \\
\hline Environment & + & $.408 * *$ & 6.910 \\
\hline Economic & + & $.211^{* *}$ & 3.531 \\
\hline $\mathrm{R}$ & & .567 & \\
\hline $\mathrm{R}^{2}$ & & .321 & \\
\hline Adjusted $\mathrm{R}^{2}$ & & .313 & \\
\hline Durbin-Watson & & 1.671 & \\
\hline \begin{tabular}{c|}
$\mathrm{F}$ \\
\end{tabular} & & $38.34 * *$ & \\
\hline
\end{tabular}

Besides, the regression analysis results showed that environmental sustainability practice has positively and significantly influence company performance $(\beta=-.408, p<0.001$. From the results, the environmental sustainability practice has a higher impact compared to the other two variables, which can be seen in Beta weights that compare the significant importance of the independent variables. Economic sustainability practice was also positively and significantly influence company performance $(\beta=.211, p<0.001)$. Meanwhile, social sustainability practice did not significantly influence the company performance and the direction is also in an inverse direction than predicted $(\beta=-.094, p>0.001)$. Thus it can be concluded that social sustainability practices do not influence company performance.

\section{Conclusion and Future Recommendation}

This study found a significant direct positive relationship between environmental sustainability practice and company performance. This finding is consistent with prior studies (Haddach et al., 2016; Maletic, Maletic, Dahlgaard, Dahlgaard-Park, \& Gomiscek, 2016; Saeidi et al., 2014). Thus, companies that actively involved in promoting and protecting the environment are better in terms of their performance. In the Malaysia construction industry, the environmental sustainability practice of sustainability or 'being environmentally friendly' has long been promoted for the past few years. The Malaysian government gave special attention to the environment by encouraging and giving support to any developers that want to actively adopt the concept of 'green technology'. The Green Technology Roadmap is one of the Malaysia government's initiatives to encourage and further educate the construction industry on this practice of sustainability (Kamar \& Hamid, 2012).

The result of Regression analysis also found that economic sustainability practice is positively and significantly influence company performance. An increase in the economic sustainability practices in company activities are likely to increase company performance. The finding of the study is similar to the studies conducted by Maletic et al. (2015) and Saeidi et al. (2014). Both of these studies found that a company that actively practices economic sustainability has successfully increased its performance in financial terms and able to improved innovation activities. Also, Eccles, Ioannou, and Serafeim (2014) found that sustainability practices have a positive impact on companies' performance because high sustainability companies are expected to be committed towards stakeholders, focused on long-term outcomes, and displayed high levels of transparency in reporting. As such, we can conclude that the performance of companies with high sustainability practices is better compared to other companies in respects of share price and financial performance.

Next, the study found that the social sustainability practice does not influence company performance. The finding of this study is parallel with the results of prior studies such as Haddach et al. (2016) and Maletic et al. (2015). According to Carrol and Buchholtz (2015) social sustainability practices which consist of philanthropic, sponsorship and social programs had little strategic and operational impact on the company compared to economic sustainability practices. This is because economic and social sustainability practices are normally conflicting with each other. Thus, this might be the reason why social sustainability practices do not affect the performance of companies in the construction industry. 
Finally, the company size was found to have no moderating effect on the relationship between social, environment and economic sustainability practices and company performance. The unexpected finding may be due to the majority of the construction companies involved in the study are considered to be small in size. Furthermore, the lack of understanding and the 'complacent norm' of construction companies with the current practices may contribute to the low sustainability practices in Malaysia specifically construction companies. In addition, according to Ikau and Joseph (2017) lack of strict enforcement through laws and legislations is another major challenges that the construction companies face in implementing sustainability. All of these factors if not deal properly may jeopardize the government commitment to the United Nation Agenda 2030 for Sustainable Development Goals.

As the present study focused on companies in the construction industry located at Kuala Lumpur and Selangor, the generalization of the study is limited to the sampled being studies. This study suggests future research that replicates this study should validate the present finding in other industry and extends to a wider geographical location. In terms of data collection, this study used a survey questionnaire as the main source of data, future study may use interview or other methods of data collection to get more in-depth understanding as to the factors that influence and encourage companies to involve in sustainability practices, which resulted in higher performance. In addition, multiple methods of measuring the company's performance can also be looked into and used in future research.

Sustainability has taken on increased importance for the construction industry specifically in the recent years. This has seen a number of construction companies in Malaysia take a strong leadership role in implementing sustainability best practices. This should provide a catalyst to other construction companies in Malaysia, particularly with the latest Bursa Malaysia Listing Requirement directive that requires all companies to provide a sustainability statement in annual reports is now mandatory from 2018. It is hoped that the level of sustainability practices among Malaysian companies specifically in the construction industry will be improved in light of the new Bursa Malaysia Listing Requirements.

Overall, there are still challenges exist for Malaysia construction companies to develop and practice sustainability in their daily operations. These include extending the implementation of sustainability further to include both large and small construction companies, increasing construction industry awareness of sustainability issues, strengthen the enforcement of laws and legislations, and the provision of tax incentives to encourage construction companies to implement sustainability. Addressing these challenges will see a better culture change in the construction industry and practice on sustainability is integrated into all aspects of the construction companies, specifically in Malaysia context.

\section{References}

Abbasi, A., \& Malik, Q. A. (2015). Firms' size moderating financial performance in growing firms: An empirical evidence from Pakistan. International Journal of Economics and Financial Issues, 5(2), 334-339.

Amah, E., Daminabo-Weje, M., \& Dosunmu, R. (2013). Size and organizational effectiveness: Maintaining a balance. Advances in Management \& Applied Economics, 3(5), 115-123.

Balabanis, G., Phillips, H. C., \& Lyall, J. (1998). Corporate social responsibility and economic performance in the top British companies: Are they linked? European Business Review, 98(1), 25-44.

Beaver, W. H., Griffin, P. A., \& Landsman, W. R. (1985). The incremental information content of replacement cost earnings. Journal of Accounting and Economics, 4(1), 15-39.

Becker, B., \& Gerhart, B. (1996). The impact of human resource management on organizational performance: Progress and prospects. Academy of Management Journal, 39(4), 779-801.

Carrol, A. B., \& Buchholtz, A. K. (2015). Business \& society: Ethics, sustainability and stakeholder management (9th ed.). USA: Cengage Learning.

Chan, T. K. (2009). Measuring performance of the Malaysian construction industry. Construction Management and Economics, 27(12), 1231-1244. Available at: https://doi.org/10.1080/01446190903233137.

Chang, R. D., Zuo, J., Zhoa, Z. Y., Zillante, G., Gan, X. L., \& Seobarto, V. (2017). Evolving theories of sustainability and firms: History, future directions and implications for renewable energy research. Renewable and Sustainable Energy Reviews, 72(2017), 48-56.

Choi, Y., \& Yu, Y. (2014). The influence of perceived corporate sustainability practices on employee and organisational performance. Sustainability, 6(1), 348-364.

Cody, A. M., Hegeman, G. B., \& Shanks, D. C. (1987). How to reduce the size of the organization but increase effectiveness. Journal of Business Strategy, 8(1), 66-70. Available at: https://doi.org/10.1 108/eb039189.

D’amato, A., Henderson, S., \& Florence, S. (2009). Corporate social responsibility and sustainable business: A guide to leadership tasks and functions. North Carolina: CCL Press.

Department of Statistics Malaysia. (2018). Annual economic statistics 2018: Construction. Retrieved from https://www.dosm.gov.my/v1/index.php?r=column/pdfPrev\&id=dmdCbDFpaW96WkFmWjZZLoxma1hFU $\underline{\text { To9. }}$

Doğan, M. (2013). Does firm size affect the firm profitability? Evidence from Turkey. Research Journal of Finance, 4(4), 5359.

Eccles, R. G., Ioannou, I., \& Serafeim, G. (2014). The impact of corporate sustainability on organizational processes and performance. Management Science, 6O(11), 2381-2617. Available at: https://doi.org/10.1287/mnsc.2014.1984.

Elkington, J. (1997). Cannibals with forks: The triple bottom line of twenty-first century business. Capstone: Oxford. 
Elkingtone, J. (1998). Partnerships from cannibals with forks: The triple bottom line of 21 st-century business. Environmental Quality Management, 8(1), 37-51.

Friedl, G., \& Deuschinger, L. (2008). A note on economic value added (EVA). München, Germany: Technische Universität Muenchen.

Haddach, A., Ammari, M., \& Laglaoui, A. (2016). Role of lean, environmental and social practices to increasing firm's overall performance. Journal of Materials and Environmental Science, 7(2), 505-512.

Hair, J. F., Babin, B. J., \& Black, C. W. (1995). Multivariate data analysis with readings (4th ed.). USA: Pearson.

Ikau, R., \& Joseph, C. (2017). Environmental legislation awareness among construction contractors in Malaysia. International Journal of Service Management and Sustainability, 2(2), 22-42.

Kamar, K. A. M., \& Hamid, Z. A. (2012). Sustainable construction of green building: The case of Malaysia. Sustainability Today, 167, 15-22.

Kaplan, R. S., \& Norton, D. P. (1992). The balanced scorecard: Measures that drive performance. Harvard Business Review, $50(1), 71-79$.

Kaplan, R. S., \& Norton, D. P. (1996). Using the balanced scorecard as a strategic management system. Harvard Business Revierw, 74, 75-85.

Kaplan, R. S., Norton, D. P., \& Rugelsjoen, B. (2010). Managing Alliance with the balanced scorecard. Harvard Business Review, 158(1), 114-120.

Kaplans, N. M. (2010). Kaplan's clinical hypertension: Lippincott Williams \& Wilkins.

Maletic, M., Maletic, D., Dahlgaard, J., Dahlgaard-Park, S., \& Gomiscek, B. (2015). Do corporate sustainability practices enhance organizational economic performance? International Journal of Quality and Service Sciences, 7(3), 184-200. Available at: https://doi.org/10.1108/IJQSS-02-2015-0025.

Maletic, M., Maletic, D., Dahlgaard, J., Dahlgaard-Park, S., \& Gomiscek, B. (2016). Effect of sustainability-oriented innovation practices on the overall organisational performance: An empirical examination. Total Quality Management and Business Excellence, 27(9-10), 1171-1190. Available at: https://doi.org/10.1080/14783363.2015.1064767.

Marshall, D., \& McCarthy, L. (2013). Impact of customer sustainability pressure on the relationship between social supply chain sustainability practices and outcomes. Paper presented at the Proceedings of 24th POMS Annual Conference. Denver.

Newell, G., \& Manaf, Z. (2008). The significance of sustainability practices by Malaysian property sector. Local Economy, $23(3), 152-167$.

Niresh, A., \& Thirunavukkarasu, V. (2014). Firm size and profitability: A study of listed manufacturing firms in Sri Lanka. International Journal of Business and Management, 9(4), 1-8.

Ofori, G. (1990). The construction industry: Aspects of its economics and management. Kent Ridge, Singapore: Singapore University Press.

Orlitzky, M., Schmidt, F. L., \& Rynes, S. L. (2003). Corporate social and financial performance: A meta-analysis. Organization Studies, 24(3), 403-441.

Otley, D. (2003). Management control and performance management: Whence and whither? British Accounting Revierw, 35(4), 309-326. Available at: https://doi.org/10.1016/j.bar.2003.08.002.

Pervan, M., \& Višić, J. (2012). Influence of firm size on its business success. Croatian Operational Research Revierw, 3(1), 213223.

Real, J. C., Roldán, J. L., \& Leal, A. (2014). From entrepreneurial orientation and learning orientation to business performance: Analysing the mediating role of organizational learning and the moderating effects of organizational size. British Journal of Management, 25(2), 186-208. Available at: https://doi.org/10.1111/j.14678551.2012.00848.x.

Rigby, D., \& Bilodeau, B. (2014). Bain and company's management tools and trends survey. Retrieved from Bain \& Company. Retrieved from http://www.bain.com/publications/articles/management-tools-and-trends-2013.aspx.

Roodman, D. M., \& Lenssen, N. (1995). A building revolution: How ecology and health concerns are transforming construction. Worldwatch Institute Paper, No. 124.

Ryan, N. (2011). Economic value added versus profit-based measures of performance (pp. 1): ACCA (Association of Chartered Certified Accountants) Student Accountant Technical.

Saeidi, S., Sofian, S., Saeidi, P., Saeidi, S., \& Saaeidi, S. (2014). How does corporate social responsibility contribute to firm financial performance? The mediating role of competitive advantage, reputation, and customer satisfaction. Journal of Business Research, 68(2), 341-350. Available at: https://doi.org/10.1016/j.jbusres.2014.06.024.

Shehata, M. (1991). Self-selection bias and the economic consequences of accounting regulation: An application of twostage switching regression to SFAS No. 2. The Accounting Review, 66(4), 768-787.

Stenzel, P. L. (2010). Sustainability, the triple bottom line, and the global reporting initiative. Global Edge Business Revierw, $4(6), 1-2$.

Surajit, B., \& Saxena, A. (2009). Does the firm size matter? An empirical enquiry into the performance of Indian manufacturing firms. Retrieved from https://ssrn.com/abstract=1300293.

United Nations General Assembly. (1987). Report of the world commission on environment and development: Our common future. Oslo, Norway: United Nations General Assembly, Development and International Co-operation: Environment.

Valdes-Vasquez, R., \& Klotz, L. (2012). Social sustainability considerations during planning and design: A framework of process for constructions projects. Journal of Construction Engineering and Management, 139(1), 80-89.

Veliyath, R., Ferris, S. P., \& Ramaswamy, K. (1994). Business strategy and top management compensation: The mediating effects of employment risk, firm performance and size. Journal of Business Research, 30(2), 149-159. Available at: https://doi.org/10.1016/0148-2963(94)90034-5.

Wang, C. J. (2014). Do ethical and sustainable practices matter? Effects of corporate citizenship on business performance in the hospitality industry. International Journal of Contemporary Hospitality Management, 26(6), 930-947. Available at: https://doi.org/10.1108/IJCHM-01-2013-0001. 
Weber, O., \& Remer, S. (2011). Social banks and the future of sustainable finance. London: Imprint Routledge.

Zainul, A. N. (2009). Sustainable construction in Malaysia - developers' awareness. Paper presented at the Proceeding of World Academy of Science, Engineering and Technology, 41(May 2009).

Zainul, A. N. (2010). Investigating the awareness and application of sustainable construction concept by Malaysian developers. Habitat International, 34(2010), 42 1-426.

Zairi, M., \& Peters, J. (2002). The impact of social responsibility on business performance. Managerial Auditing Journal, 17(4), 174-178. Available at: https://doi.org/10.1108/02686900210424312.

Appendix A

Survey Questionnaire

Section A: Demography

Please $(\sqrt{ })$ for your choices

1. Type of Company

Public

Private

Subsidiaries

2. Based Location

Kuala Lumpur

Selangor

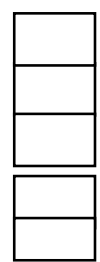

3. Years of engagement

In Construction industry :

Less 5

6-10

$11-15$

$16-20$

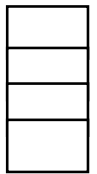

21-25

26-30

$31-40$

40 above

4. Annual Sales Turnover:

Less than RM200,000

RM200,000-RM1,000,000

RM1,000,000-RM5,000,000

RM5,000,000 above

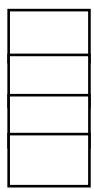

5. Current Notable Project : 
Section B - Social Sustainability Practice

Circle one of the scales below that best describe the current condition in your organization.

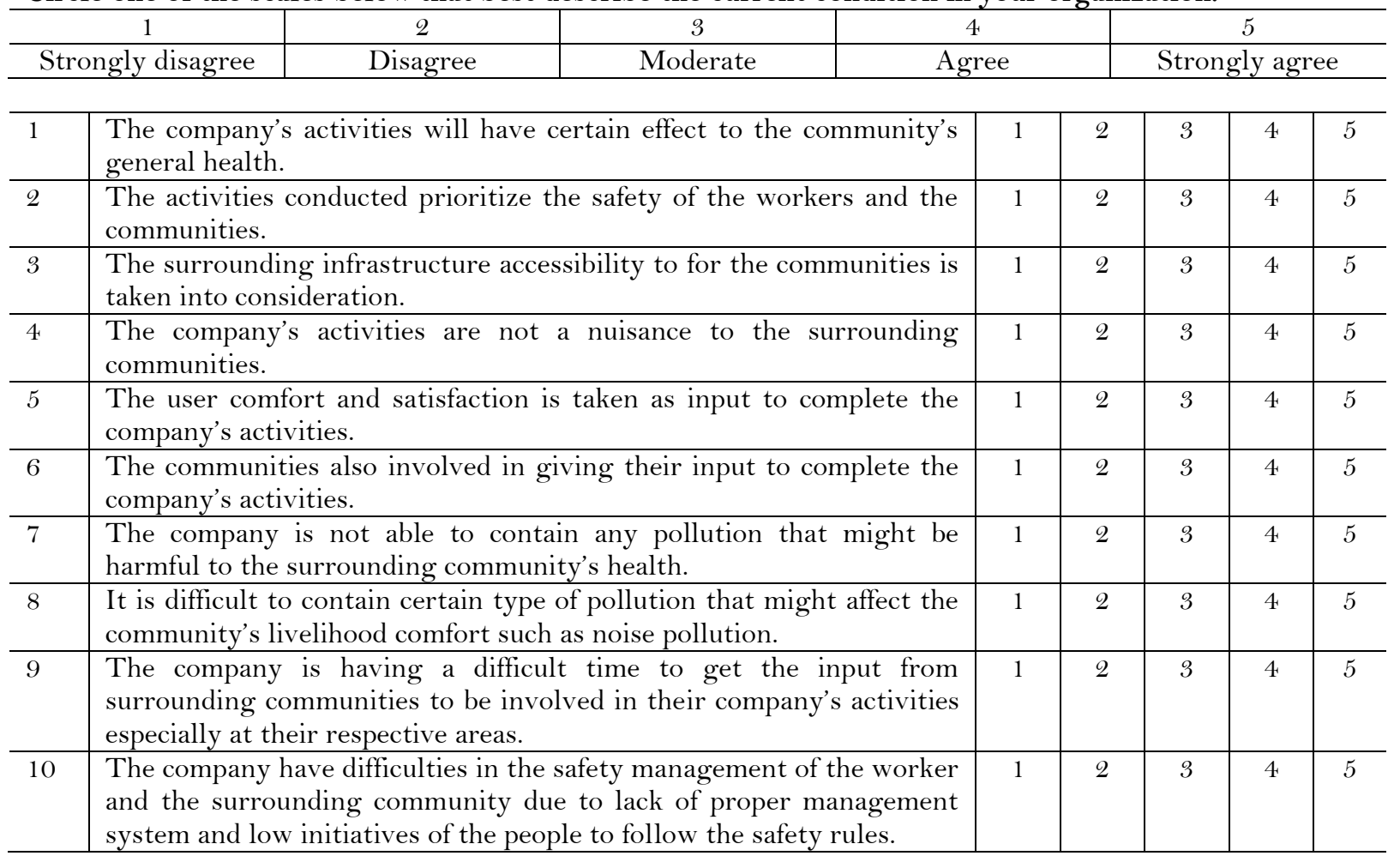

Section C - Economic Sustainability Practice

Circle one of the scales below that best describe the current condition in your organization.

\begin{tabular}{|c|c|c|c|c|c|c|c|c|}
\hline \multicolumn{6}{|c|}{4} & \multicolumn{3}{|c|}{5} \\
\hline \multicolumn{2}{|c|}{ Strongly disagree } & Disagree & Moderate & Agree & & \multicolumn{3}{|c|}{ Strongly agree } \\
\hline 1 & $\begin{array}{l}\text { The company } \\
\text { after impleme }\end{array}$ & $\begin{array}{l}\text { to reduc } \\
\text { istainabilit }\end{array}$ & or resources consumption & 1 & 2 & 3 & 4 & 5 \\
\hline 2 & $\begin{array}{l}\text { The impleme } \\
\text { enhanced the }\end{array}$ & $\begin{array}{l}\text { of sustai } \\
\text { y's ability }\end{array}$ & $\begin{array}{l}\text { company's activities has } \\
\text { more profit. }\end{array}$ & 1 & 2 & 3 & 4 & 5 \\
\hline 3 & $\begin{array}{l}\text { The sustainal } \\
\text { enhanced the }\end{array}$ & $\begin{array}{l}\text { ments inte } \\
\text { y product }\end{array}$ & the company's activities has & 1 & 2 & 3 & 4 & 5 \\
\hline 4 & The complete & ict will hav & benefits to the area. & 1 & 2 & 3 & 4 & 5 \\
\hline 5 & $\begin{array}{l}\text { The compar } \\
\text { sustainability }\end{array}$ & $\begin{array}{l}\text { porate im } \\
\text { in their ac }\end{array}$ & auch better after using & 1 & 2 & 3 & 4 & 5 \\
\hline 6 & $\begin{array}{l}\text { The company } \\
\text { needs. }\end{array}$ & o generate & hout compromising future & 1 & 2 & 3 & 4 & 5 \\
\hline 7 & $\begin{array}{l}\text { The company } \\
\text { growth after }\end{array}$ & $\begin{array}{l}\text { to maint: } \\
\text { stainability }\end{array}$ & d stable level of economic & 1 & 2 & 3 & 4 & 5 \\
\hline 8 & $\begin{array}{l}\text { It is difficult } \\
\text { current resou } \\
\text { the resources. }\end{array}$ & $\begin{array}{l}\text { erate favor } \\
\text { t may com }\end{array}$ & $\begin{array}{l}\text { without full utilization of } \\
\text { e future generation need of }\end{array}$ & 1 & 2 & 3 & 4 & 5 \\
\hline 9 & $\begin{array}{l}\text { The impleme } \\
\text { enhanced the }\end{array}$ & $\begin{array}{l}\text { of sustai } \\
\text { ts but it is } 1\end{array}$ & $\begin{array}{l}\text { company's activities has } \\
\text { ective. }\end{array}$ & 1 & 2 & 3 & 4 & 5 \\
\hline 10 & $\begin{array}{l}\text { It is difficult } \\
\text { beneficial stat }\end{array}$ & $\begin{array}{l}\text { ure that } t \\
\text { e involved }\end{array}$ & ted product to have equal & 1 & $\mathcal{Q}$ & 3 & 4 & 5 \\
\hline
\end{tabular}


Section D - Environmental Sustainability Practice

Circle one of the scales below that best describe the current condition in your organization.

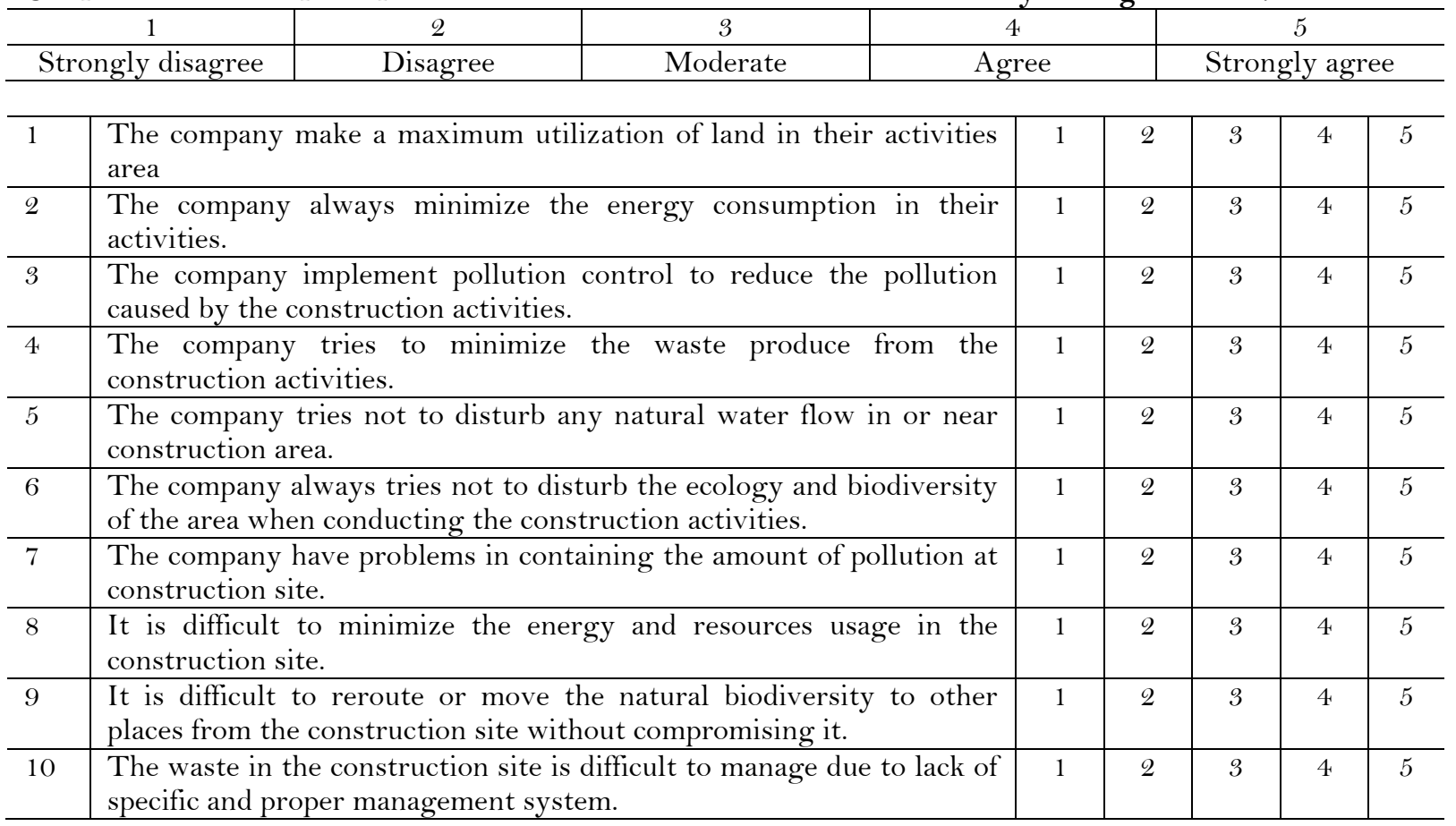

Section F - Company Performance (Financial Perspectives)

Circle one of the scales below that best describe the current condition in your organization.

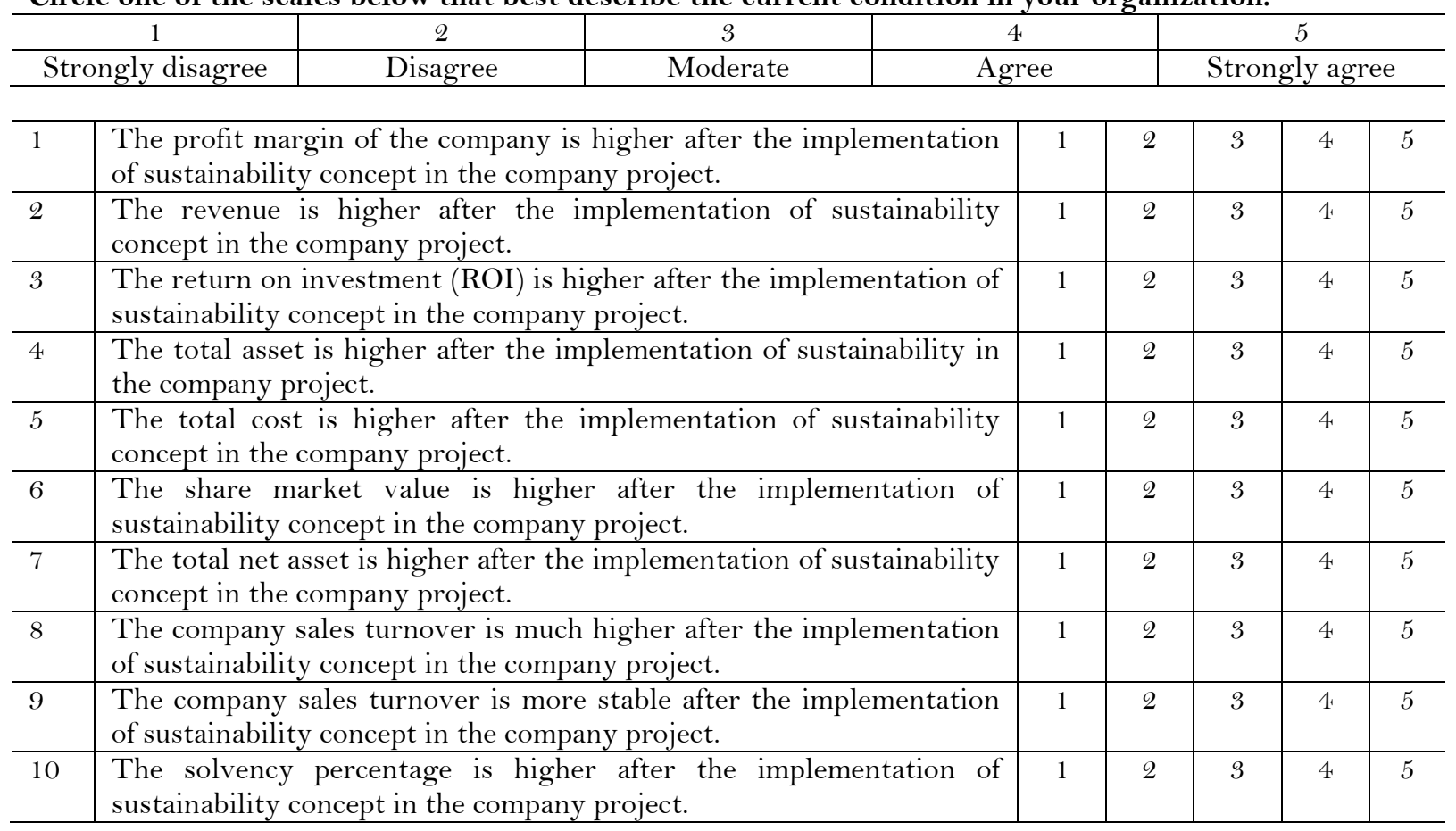


Section G - Company Performance (Internal Business Process Perspective)

Circle one of the scales below that best describe the current condition in your organization.

\begin{tabular}{|c|c|c|c|c|c|c|c|c|c|}
\hline \multirow{2}{*}{\multicolumn{2}{|c|}{$\frac{1}{\text { Strongly disagree }}$}} & 2 & 3 & \multicolumn{3}{|c|}{4} & \multicolumn{3}{|c|}{5} \\
\hline & & Disagree & Moderate & \multicolumn{3}{|c|}{ Agree } & \multicolumn{3}{|c|}{ Strongly agree } \\
\hline 1 & $\begin{array}{l}\text { The produc } \\
\text { sustainability }\end{array}$ & $\begin{array}{l}\text { rate higl } \\
t \text { in the con }\end{array}$ & $\begin{array}{l}\text { the impl } \\
\text { ct. }\end{array}$ & of & 1 & 2 & 3 & 4 & 5 \\
\hline 2 & $\begin{array}{l}\text { The invento } \\
\text { sustainability }\end{array}$ & $\begin{array}{l}\text { nover is } \\
t \text { in the con }\end{array}$ & $\begin{array}{l}\text { ir the imp } \\
\text { ct. }\end{array}$ & of & 1 & 2 & 3 & 4 & 5 \\
\hline 3 & $\begin{array}{l}\text { The time of } \\
\text { shorter after }\end{array}$ & $\begin{array}{l}\text { eting proce } \\
\text { lementatiol }\end{array}$ & $\begin{array}{l}\text { company pr } \\
\text { ability conce }\end{array}$ & & 1 & 2 & 3 & 4 & 5 \\
\hline 4 & $\begin{array}{l}\text { The time fol } \\
\text { after the imp }\end{array}$ & $\begin{array}{l}\text { ring the } p \\
\text { tion of sust }\end{array}$ & $\begin{array}{l}\text { customer is } \\
\text { oncept. }\end{array}$ & & 1 & 2 & 3 & 4 & 5 \\
\hline 5 & $\begin{array}{l}\text { The adminis } \\
\text { sustainability }\end{array}$ & $\begin{array}{l}\text { expense is } \\
t \text { in the con }\end{array}$ & $\begin{array}{l}\text { ter the imp } \\
\text { ct. }\end{array}$ & of & 1 & 2 & 3 & 4 & 5 \\
\hline 6 & $\begin{array}{l}\text { The cost of a } \\
\text { sustainability }\end{array}$ & $\begin{array}{l}\text { rative erro } \\
t \text { in the cor }\end{array}$ & $\begin{array}{l}\text { after the im } \\
\text { ct. }\end{array}$ & of & 1 & 2 & 3 & 4 & 5 \\
\hline 7 & $\begin{array}{l}\text { The time for } \\
\text { sustainability }\end{array}$ & $\begin{array}{l}\text { on making } \\
t \text { in the cor }\end{array}$ & $\begin{array}{l}\text { fter the imp } \\
\text { ct }\end{array}$ & & 1 & 2 & 3 & 4 & 5 \\
\hline 8 & $\begin{array}{l}\text { The number } \\
\text { after the imp }\end{array}$ & $\begin{array}{l}\text { ect or cont } \\
\text { tion of sust }\end{array}$ & $\begin{array}{l}\text { without er } \\
\text { oncept. }\end{array}$ & & 1 & 2 & 3 & 4 & 5 \\
\hline 9 & $\begin{array}{l}\text { The compan } \\
\text { environment }\end{array}$ & $\begin{array}{l}\text { nstruction } \\
\text { e sustainab }\end{array}$ & $\begin{array}{l}\text { have less } \\
\text { t implemen }\end{array}$ & & 1 & 2 & 3 & 4 & 5 \\
\hline 10 & $\begin{array}{l}\text { The industr } \\
\text { sustainability }\end{array}$ & $\begin{array}{l}\text { ident is } \\
t \text { in the cor }\end{array}$ & $\begin{array}{l}r \text { the imp } \\
\text { ct. }\end{array}$ & of & 1 & 2 & 3 & 4 & 5 \\
\hline
\end{tabular}

Section H - Company Performance (Learning and Growth Perspective)

Circle one of the scales below that best describe the current condition in your organization.

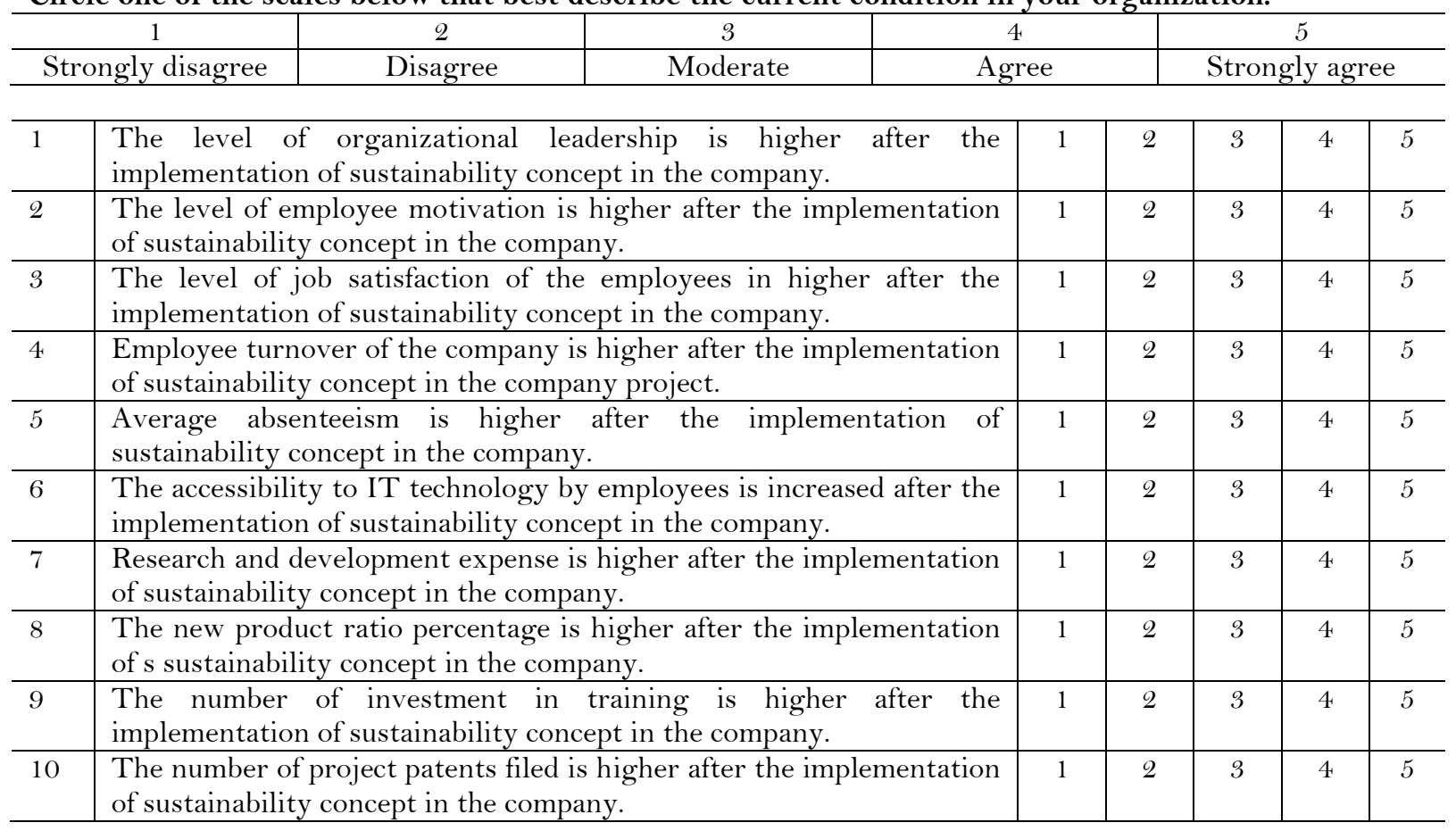


Section I - Company Performance (Customer Perspective)

Circle one of the scales below that best describe the current condition in your organization.

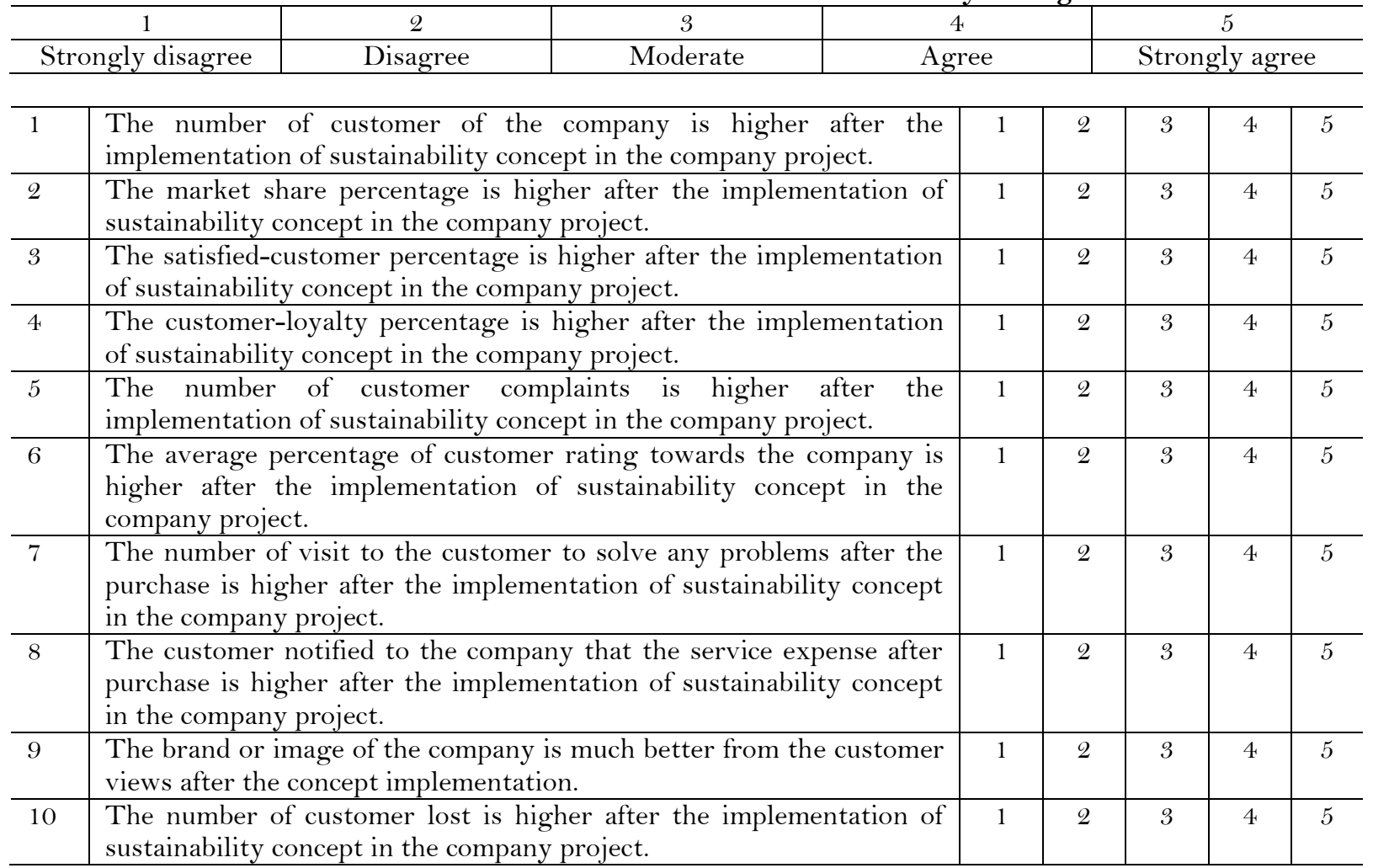

